\title{
Effects of Temperature on Time Dependent Rheological Characteristics of Koumiss
}

\author{
Serdal Sabancı $^{1}$, Ömer Faruk Çokgezme ${ }^{1}$, DeryaTezcan ${ }^{1}$, Mutlu Çevik ${ }^{1}$, Filiz Içier $^{2 *}$
}

${ }^{1}$ Food Engineering Program, Graduate School of Natural and Applied Sciences, Ege University, 35100 Bornova/Izmir, Turkey ${ }^{2}$ Food Engineering Department,' Engineering Faculty, Ege University, 35100 Bornova/Izmir, Turkey

\begin{tabular}{|c|c|}
\hline A R T I C L E I N F O & A B S T R A C T \\
\hline $\begin{array}{l}\text { Article history: } \\
\text { Received 09 September } 2015 \\
\text { Accepted } 17 \text { March } 2016 \\
\text { Available online, ISSN: } 2148-127 \mathrm{X}\end{array}$ & $\begin{array}{l}\text { The rheological properties of koumiss were investigated at different temperatures }(4,10 \text {, } \\
\text { and } 20^{\circ} \mathrm{C} \text { ). Experimental shear stress-shear rate data were fitted to different rheological } \\
\text { models. The consistency of koumiss was predicted by using the power-law model since it } \\
\text { described the consistency of koumiss best with highest regression coefficient and lowest } \\
\text { errors (root mean square error and chi-square). Koumiss exhibited shear thinning }\end{array}$ \\
\hline $\begin{array}{l}\text { Keywords: } \\
\text { Koumiss }\end{array}$ & $\begin{array}{l}\text { was } 25.532 \mathrm{~kJ} / \mathrm{mol} \text {, and the frequency constant was } 2.18 \times 10^{-7} \mathrm{~Pa} . \mathrm{s}^{\mathrm{n}} \text {. As the temperature } \\
\text { increased the time dependent thixotropic characteristics of koumiss decreased. }\end{array}$ \\
\hline
\end{tabular}

Mare's milk

Rheology

Low temperature

\begin{tabular}{|c|c|}
\hline & *Corresponding Author: \\
\hline
\end{tabular}

\section{Introduction}

There are numerous reasons for fermenting milk although the primary function is to extend its shelf-life. Other advantages, such as taste improvement, enhancing the digestibility of the product and the manufacture of a wide range of products (i.e. from yoghurt to concentrated yoghurt to cheese) are also remarkable. Fermented milk products, which are made with certain strains of lactic acid bacteria and yeasts, are classified as yeast-lactic fermentations, and koumiss is one of the typical examples (Kurman et al., 1992; Tamime, 2006). The sensory attributes are the result of the production of lactic acid, carbon dioxide, alcohol and other flavouring compounds formed during the fermentation stage of the milk (Honer, 1992; Kroger, 1992; Simova et al., 2002). Koumiss (also known as koumyss, kumiss, kumys, kumyz, kimiz or coomys) is a fermented milk drink traditionally produced from mare's milk. It is also produced from camel's milk in Mongolia while a koumiss-like product is made from full or skimmed cow's milk in Europe and North America (Mann, 1989; Di Cagno et al., 2004).

The rheology of koumiss concerning the flow characteristics and its deformation under applied forces is explained by the relationship between the stress acting on the koumiss sample and the resulting deformation and/or flow taking place (Bozkurt and Icier, 2009). Rheological properties of fermented milk products are important parameters in the design of pumping systems, heat exchangers, evaporators, mixing systems, and for the development of new products. Several methods have been used to describe the flow behavior of fluid foods, for example linear (Newtonian or Bingham), power-law (Ostwald-de-Waele), and power-law with yield stress (Herschel-Bulkley). Power-law model is the most widely employed model for non-Newtonian milk products, and is used extensively to describe their flow properties in practical engineering applications (Marcotte et al., 2001).

The gel formation is the most important physical property of fermented milk products. Milk composition, dry matter content, heating, homogenization, incubation temperature, cooling, storage time have an important influence on rheological characteristics of milk gel (Bensmira et al., 2010). A high consistency index or high pseudoplasticity was correlated positively with the sensory acceptability of lactic beverages (Köksoy and Kilic, 2003). Janhoj et al. (2008) reported that the addition of acidified milk to increase the dry matter content, increased the consistency coefficient, and changed the fluid characteristics from Newtonian to non-Newtonian . Ayran samples sold in retail markets in Turkey were found to be non-Newtonian shear thinning type fluid 
having thixotropic characteristics (Köksoy and Kilic, 2003). In other research, Di Cagno et al (2004) reported that fermented mare's milk showed shear thinning flow behavior fitting to the power-law model. On the other hand, there are limited information on effects of temperature on thixotropic characteristics of fermented milk products such as koumiss in the literature. Since koumiss is consumed below room temperature by consumers, the time dependency of thixotropic characteristics at these temperatures should be known to characterize its rheological stability.

In the present study, the rheological properties of koumiss were investigated at different temperatures (4, 10 , and $\left.20^{\circ} \mathrm{C}\right)$ and different shear rates $(0-2641 / \mathrm{s})$. The suitability of different rheological models was assessed statistically to determine the best model describing the rheological characteristics of koumiss. The time dependency of rheological properties of koumiss at different temperatures was investigated.

\section{Materials and Methods}

\section{Material}

Koumiss was supplied from local horse farm in İzmir. The composition of koumiss was obtained from the supplier as follows; $0.8-\%$ fat, 3.8-\% total carbohydrates, $2.2-\%$ total protein, and $0.5-\%$ ash. The alcohol content of the koumiss was $1.7-\%$. It was transported to the laboratory in cold conditions, and stored at $4^{\circ} \mathrm{C}$.

\section{Rheological Measurements}

Rheological properties were measured using a concentric cylinder type viscometer (Brookfield LVDVII, USA). Rheological measurements of koumiss were carried out at three different temperatures (4, 10, and $20^{\circ} \mathrm{C}$ ). The prescribed temperatures were maintained by the use of the cylindrical concentric adapter of the rheometer (Brookfield small adapter, USA) and the circulated cold water bath (PoliScience, USA) during the measurements. The measurement range of viscometer for 5 and $100 \%$ full scale torques was adjusted by selecting both the specific spindle (S-18) and its rotational speed (0.0-200 rpm). During the rheological measurement, shear stress (SS), shear rate (SR), viscosity (cp) and \% torque $(\mathrm{T})$ values were recorded for each rotational speed (rpm). The experimental shear stress-shear rate data were fitted to selected rheological models to obtain viscous properties of koumiss. Four different rheological models were applied to find the suitable rheological model fitting the experimental data; Newtonian model Equation (1), power-law model Equation (2), Bingham model Equation (3) and Herschel-Bulkley model Equation (4) (Bozkurt and Icier, 2009):

$$
\sigma=\eta \cdot \dot{\gamma}
$$

where $\eta$ is Newtonian viscosity $(\mathrm{Pa} \cdot \mathrm{s}), \sigma$ is shear stress (Pa) and $\dot{\gamma}$ is shear rate $\left(\mathrm{s}^{-1}\right)$;

$$
\begin{aligned}
& \sigma=K \cdot(\gamma)^{n} \\
& \sigma-\sigma_{0}=K \cdot \dot{\gamma} \\
& \sigma-\sigma_{0}=K \cdot(\dot{\gamma})^{n}
\end{aligned}
$$

where $K$ is the consistency coefficient $\left(\mathrm{Pa} \cdot \mathrm{s}^{\mathrm{n}}\right), \sigma_{0}$ is yield stress (Pa) and $n$ is the flow behavior index (dimensionless).

The time dependency of rheological properties of koumiss was investigated. If viscosity decreases as time increases and then returns to the initial level on rest after shearing, such a phenomenon is called thixotropy. The reverse phenomenon is called rheopexy (Malkin, 1994). Thixotropic and/or rheopectic character of koumiss was determined by analyzing hysteresis loop between forward and backward shear stress-shear rate relations. According to the procedure of the rheometer used, the shear stressshear rate data having the torque measurement values below $5 \%$ were not used in calculations of time dependency values. The corresponding shear rates values used in the prediction of time dependency were in the range of $92-264 \mathrm{~s}^{1}$.

To investigate the time dependency, the area below the forward shear stress-shear rate curve was defined as $\mathrm{A}_{1}$ while the area below the backward shear stress-shear rate curve was defined as $\mathrm{A}_{2}$. The polynomial fitting of the experimental shear stress-shear rate curves was considered. The area between the upward $\left(A_{1}\right)$ and downward flow curves $\left(\mathrm{A}_{2}\right)$ of the hysteresis loop was calculated by Simpson's rule Equation (5) (Geankoplis, 2003). This area has the dimensions of power per unit volume $\left(\mathrm{Pa} \mathrm{s} \mathrm{s}^{-1}\right.$ or $\mathrm{ML}^{2} \mathrm{~T}^{-3} / \mathrm{L}^{3}=\mathrm{ML}^{-1} \mathrm{~T}^{-3}$, where $\mathrm{M}$ represents the dimension of a mass, $\mathrm{L}$, length, and $\mathrm{T}$, time) and corresponds to the power necessary to break down the thixotropic structure of a given volume of solution (Benchabane and Bekkour, 2008).

The calculation of areas under the upward $\left(A_{1}\right)$ and downward curves $\left(\mathrm{A}_{2}\right)$ was conducted by using graphical integration method (Eq. 5) (Geankoplis, 2003);

$$
\begin{aligned}
& \int_{a}^{b} f(x) d x=\frac{h}{3}\left[\left(y_{0}+y_{n}\right)+4\left(y_{1}+y_{3}+. .+y_{n-1}\right)+\right. \\
& \left.2\left(y_{2}+y_{4}+. .+y_{n-2}\right)\right]
\end{aligned}
$$

The time dependency characteristic of koumiss was also investigated by predicting the thixotropic index (Equation 6). The thixotropic index, $\alpha$, was calculated by reporting the area of the thixotropic loop $\left(A_{1}-A_{2}\right)$ to the area under the upward flow curve $\left(\mathrm{A}_{1}\right)$ as percent (Eq.6) (Benchabane and Bekkour, 2008).

$$
\alpha=\frac{\left(A_{1}-A_{2}\right)}{A_{1}} 100
$$


The effect of temperature on $\mathrm{K}$ and thixotropic index was described by the Arrhenius relationship (Equations 7 and 8);

$$
\begin{aligned}
& \mathrm{K}=K_{0} \exp \left(\mathrm{E}_{a} / \mathrm{RT}\right) \\
& \alpha=\alpha_{0} \exp \left(\mathrm{E}_{a, \alpha} / \mathrm{RT}\right)
\end{aligned}
$$

where $K_{0}\left(\mathrm{~Pa}_{\mathrm{s}}^{\mathrm{n}}\right)$ and $\alpha_{0}$ (dimensionless) are the frequency factors, $E_{a}$ and $E_{a, a}$ are the activation energy terms $(\mathrm{kJ} / \mathrm{mol}), \mathrm{T}$ is the temperature (Kelvin, $\mathrm{K})$, and $\mathrm{R}$ is universal gas constant $(\mathrm{kJ} / \mathrm{mol} \cdot \mathrm{K})$. When Equations (7) or (8) are linearized, frequency factor is the exponential of the $y$-intercept and the activation energy is the product of slope.

\section{Statistical Analysis}

All experiments and measurements were carried out in triplicate. The ANOVA and Duncan tests were applied to determine the effects of temperature on rheological properties by using statistical software package (SPSS v20, 2012). The confidence level was 95\%. The compatibility of the model with experimental data was determined by using a non-linear regression analysis. Regression coefficient $\left(\mathrm{R}^{2}\right)$; root mean square error (RMSE, Equation 9) and chi-square ( $\chi^{2}$, Equation 10) values were calculated. The statistical criteria of having highest $\mathrm{R}^{2}$, lowest RMSE and lowest $\chi^{2}$ were chosen for selection of best model for fitting (Sabanc1 et al., 2014).

$$
\begin{aligned}
& \mathrm{RMSE}=\left\lceil\frac{1}{N} \sum_{i=1}^{n}\left(K G_{\text {predicted }, i}-K G_{\text {experimental }, i}\right)^{2}\right]^{0.5}(9) \\
& \chi^{2}=\frac{\sum_{i=1}^{n}\left(K G_{\text {predicted }, i}-K G_{\text {experimental }, i}\right)^{2}}{N-n}
\end{aligned}
$$

where $K G$ is rheological data (experimental and predicted), $i$ is observation values at i experiment, $N$ is observation number, and $n$ is number of parameters in model.

\section{Results and Discussion}

Since koumiss is a fermented milk product consumed as the cold drink, the rheological properties were determined at the cold storage and the consumption temperature range for koumiss. The experimental shear stress versus shear rate rheograms for different temperatures were determined (Fig 1). As expected for the same shear rate values in the range of $0-264 \mathrm{~s}^{-1}$, the shear stress values decreased as the temperature increased $(\mathrm{P}<0.05)$. Kristensen et al (1997) reported that the shear stress values of dairy products for the shear rate values in a range of $0-500 \mathrm{~s}^{-1}$ decreased as the temperature increased $\left(0-40^{\circ} \mathrm{C}\right)$. Similarly, Icier and Bozkurt (2010) heated the milk samples with two different heating process (ohmic and conventional). They reported that the shear stress values for the shear rate values in the range of $0-264 \mathrm{~s}^{-1}$ decreased as the temperature increased in the range of $20-80^{\circ} \mathrm{C}$.

The statistical compatibility of experimental data to some rheological models for different temperatures were investigated (Table 1). RMSE and $\chi^{2}$ values were used as the statistical criteria to assess the suitability of the rheological models describing the rheological characteristics of koumiss. Although the highest $\mathrm{R}^{2}$ were determined for Hershel-Bulkley model, the lowest RMSE and $\chi^{2}$ values were obtained for power-law model (Table 1). Since power-law model had higher $R^{2}$ and lower error values (RMSE and $\chi^{2}$ ) for all temperature values studied, this model was selected as the best rheological model describing the rheological properties of koumiss (Table 1). It was determined that $\mathrm{R}^{2}, \mathrm{RMSE}$ and $\chi^{2}$ values of power-law model were between 0.977-0.988, 0.016-0.024 and 0.000-0.001, respectively. The observed results from present study will make an important contribution to current literature. Kristensen et al (1997) investigated the suitability of three different rheological models for a dairy product, and reported that most suitable model was power-law model. Similarly, Köksoy and Kılıc (2003) reported that the rheological properties of ayran at $10^{\circ} \mathrm{C}$ were described best with the power-law model.

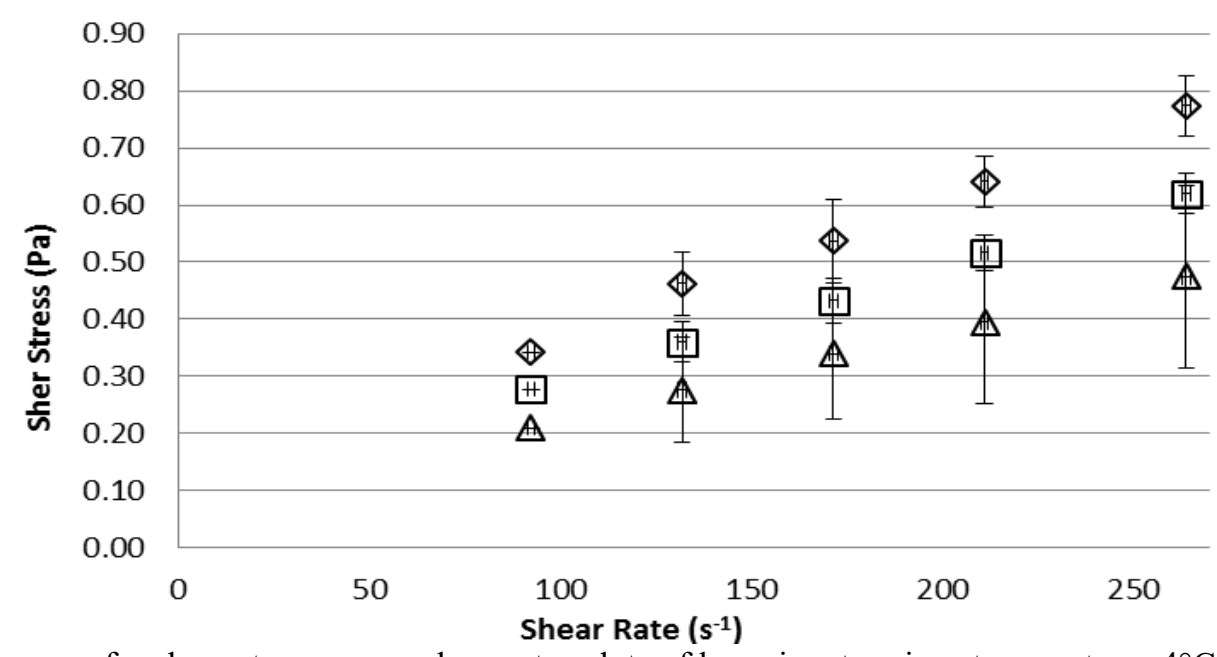

Figure 1 Rheograms for shear stress versus shear rates plots of koumiss at various temperatures $4^{\circ} \mathrm{C}(\diamond), 10^{\circ} \mathrm{C}(\square)$, and $20^{\circ} \mathrm{C}(\Delta)$ 
Table 1 The statistical evaluation of rheological models applied to fit the experimental shear stress-shear rate data for koumiss at different temperatures

\begin{tabular}{c|lcccc}
\hline \multirow{2}{*}{ Temperature $\left({ }^{\circ} \mathrm{C}\right)$} & $\begin{array}{c}\text { Statistical } \\
\text { Criteria }\end{array}$ & $\begin{array}{c}\text { Newton } \\
\text { model }\end{array}$ & $\begin{array}{c}\text { Bingham } \\
\text { model }\end{array}$ & Power-law model & $\begin{array}{c}\text { Hershel-Bulkley } \\
\text { model }\end{array}$ \\
\cline { 3 - 6 } & $\mathrm{R}^{2}$ & $0.928 \pm 0.039$ & $0.978 \pm 0.018$ & $0.977 \pm 0.020$ & $0.980 \pm 0.019$ \\
& $\mathrm{RMSE}$ & $0.096 \pm 0.073$ & $0.044 \pm 0.021$ & $0.027 \pm 0.012$ & $0.087 \pm 0.099$ \\
& $\chi^{2}$ & $0.006 \pm 0.003$ & $0.003 \pm 0.002$ & $0.001 \pm 0.001$ & $0.020 \pm 0.039$ \\
\hline \multirow{2}{*}{10} & $\mathrm{R}^{2}$ & $0.907 \pm 0.080$ & $0.987 \pm 0.011$ & $0.987 \pm 0.010$ & $0.989 \pm 0.012$ \\
& $\mathrm{RMSE}$ & $0.052 \pm 0.014$ & $0.057 \pm 0.028$ & $0.024 \pm 0.012$ & $0.089 \pm 0.093$ \\
& $\chi^{2}$ & $0.003 \pm 0.002$ & $0.005 \pm 0.004$ & $0.001 \pm 0.001$ & $0.019 \pm 0.028$ \\
\hline \multirow{2}{*}{20} & $\mathrm{R}^{2}$ & $0.897 \pm 0.041$ & $0.988 \pm 0.008$ & $0.988 \pm 0.007$ & $0.992 \pm 0.004$ \\
& $\mathrm{RMSE}$ & $0.041 \pm 0.009$ & $0.059 \pm 0.019$ & $0.016 \pm 0.008$ & $0.031 \pm 0.018$ \\
& $\chi^{2}$ & $0.002 \pm 0.001$ & $0.004 \pm 0.003$ & $0.000 \pm 0.000$ & $0.002 \pm 0.002$ \\
\hline
\end{tabular}

Table 2 Parameters obtained from power-law equation for koumiss at different temperatures, (Eq. 2)

\begin{tabular}{|c|c|c|c|c|}
\hline Temperature $\left({ }^{\circ} \mathrm{C}\right)$ & \multicolumn{2}{|c|}{ Consistency coefficient, $\mathrm{K}$} & Flow behavior index, $\mathrm{n}$ & Coefficient of determination, $\mathrm{R}^{2}$ \\
\hline 4 & \multicolumn{2}{|l|}{$0.015 \pm 0.008^{b}$} & $0.749 \pm 0.083$ & $0.977 \pm 0.020$ \\
\hline 10 & \multicolumn{2}{|l|}{$0.010 \pm 0.005^{\mathrm{ab}}$} & $0.790 \pm 0.091$ & $0.987 \pm 0.010$ \\
\hline 20 & \multicolumn{2}{|l|}{$0.008 \pm 0.002^{\mathrm{a}}$} & $0.756 \pm 0.049$ & $0.988 \pm 0.007$ \\
\hline Table 3 Thixo & aracteristics of kou & ferent $t$ & eratures & \\
\hline Temperature $\left({ }^{\circ} \mathrm{C}\right)$ & $\begin{array}{l}\text { Thixotropic Energy } \\
\left(\mathrm{Pa} \mathrm{s}^{-1}\right) \\
\end{array}$ & $\begin{array}{c}\text { Thixotropic } \\
\text { Index }\end{array}$ & $\begin{array}{l}\text { Frequency constant in } \\
\text { Equation }(8), \alpha_{0} \\
\end{array}$ & $\begin{array}{c}\text { Activation energy } \\
\text { (Equation 8), } \mathrm{E}_{\mathrm{a}, \alpha}(\mathrm{kJ} / \mathrm{mol})\end{array}$ \\
\hline 4 & $23.236 \pm 11.817$ & $15.86 \pm 7.19$ & & \\
\hline 10 & $8.873 \pm 1.016$ & $10.09 \pm 1.46$ & $6.12 \times 10^{-6}$ & 33.92 \\
\hline 20 & $3.059 \pm 1.592$ & $6.97 \pm 2.51$ & & \\
\hline
\end{tabular}

Power-law model predictions were used to determine the time independent rheological properties of koumiss. The consistency coefficient $(\mathrm{K})$, flow behavior index (n) and the regression coefficient $\left(\mathrm{R}^{2}\right)$ values obtained from power-law model were given in Table 2 . The consistency coefficient value decreased as the temperature increased. It was determined that there was a statistically significant difference between consistency coefficients for 4 and $20^{\circ} \mathrm{C}(\mathrm{P}<0.05)$. As expected, the molecules move away from each other and cause the reduction of consistency coefficient as the temperature increased (Steffe, 1996).

By evaluating the flow behavior index, $n$, of koumiss at different temperatures, it was determined that koumiss showed Non-Newtonian shear thinning flow character for the temperature range studied. On the other hand, it was determined that the flow behavior index did not change with the temperature (Table 2). Abu-Jdayil and Mohameed (20) reported that the concentrated yogurt samples showed non-Newtonian shear thinning flow characteristics at $25^{\circ} \mathrm{C}$. Similarly, Di Cagno et al (2004) determined that the fermented milk samples showed nonNewtonian shear thinning flow characteristics at $4^{\circ} \mathrm{C}$.

The Arrhenius relationship was used to describe the effect of temperature on the consistency coefficient. The activation energy $\left(\mathrm{E}_{\mathrm{a}}\right)$ and Arrhenius constant $\left(\mathrm{K}_{0}\right)$ values for koumiss were found as $25.532 \mathrm{~kJ} / \mathrm{mol}$ and $2.18 \times 10^{-7}$ Pa.s ${ }^{\mathrm{n}}$, respectively.

The time dependency of the rheological properties of koumiss for different temperatures was examined (Fig 2). Since upward shear rate applications responded higher shear stress values then downward shear rate applications, it was concluded that koumiss showed thixotropic character. The thixotropic character of koumiss decreased as the temperature increased (Table 3). In addition, the time dependency of koumiss was also evaluated by predicting the thixotropic index as a function of temperature. It was found that there was an Arrhenius type relation (Eq.8) between the thixotropic index and temperature (Table 3). As the temperature increased the thixotropic index decreased $(\mathrm{P}<0.05)$. The activation energy $\left(E_{a, \alpha}\right)$ and Arrhenius constant $\left(\alpha_{0}\right)$ values for koumiss were found as $33.9 \mathrm{~kJ} / \mathrm{mol}$ and $6.12 \times 10^{-6}$, respectively (Table 3). Similarly, Köksoy and Kılıç (2013) had studied the effect of water-salt ratio on rheological parameters of ayran, and reported that the ayran samples showed thixotropic behavior. Abu-Jdayil and Mohammed (2002) reported that the concentrated yoghurt samples showed thixotropic character. However these researches did not discussed the effect of temperature on thixotropic characteristics.

The time dependent rheological properties were found to be more sensible to temperature changes than timeindependent rheological properties. These results showed that the time dependence of the rheological properties of koumiss may change depending on the time, temperature and shear rate during process applied. Hence, the pumping power requirement and the flow characteristics may vary during the processing of koumiss in the industrial scale. 


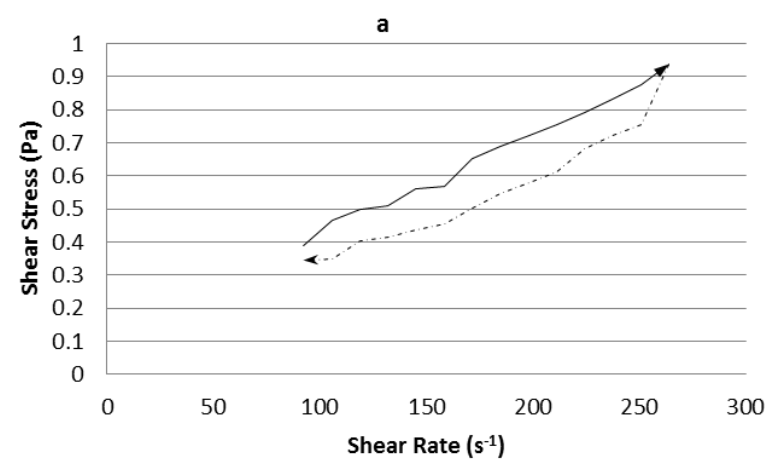

b
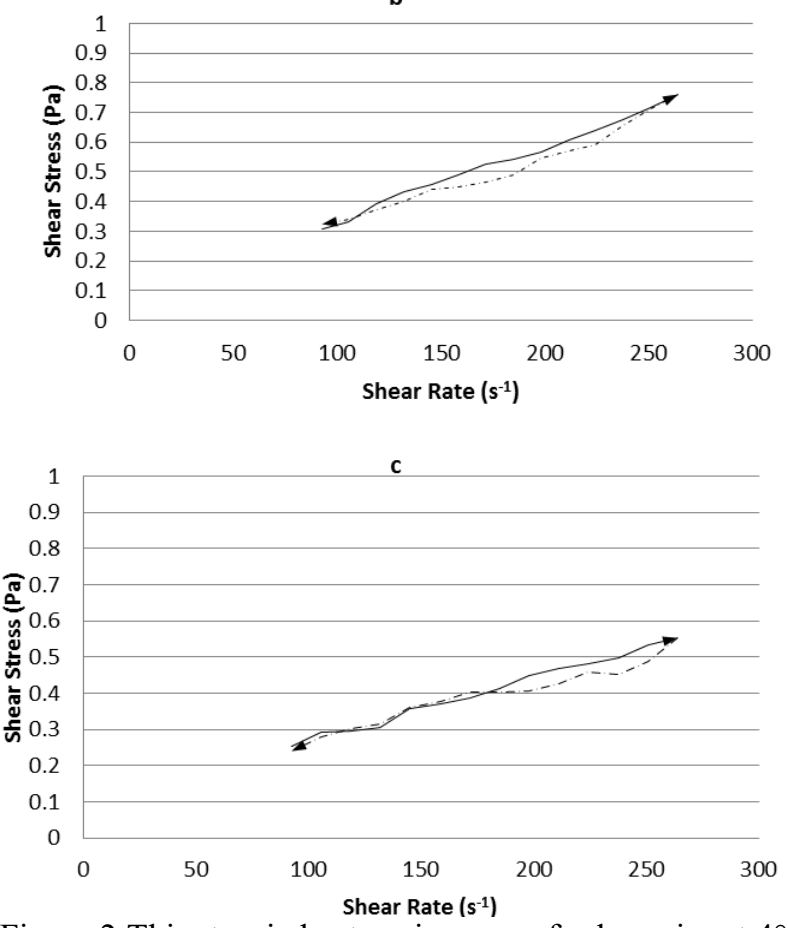

Figure 2 Thixotropic hysteresis curves for koumiss at $4^{\circ} \mathrm{C}$ (a), at $10^{\circ} \mathrm{C} \mathrm{(b),} \mathrm{at} 20^{\circ} \mathrm{C} \mathrm{(c)}$

\section{Conclusion}

In present study, the rheological properties of koumiss were investigated for different temperatures (4, 10, and $\left.20^{\circ} \mathrm{C}\right)$ and different shear rates $(0-2641 / \mathrm{s})$. It was concluded that the best suitable model describing the rheological properties of koumiss was the power-law model. Koumiss showed non-Newtonian shear thinning $(n<1)$ flow characteristic with similar flow behavior indexes for the temperature range studied. The temperature effect on the consistency coefficient was assessed by Arrhenius equation. It was determined that koumiss also showed the time dependent thixotropic behavior. The characterization of rheological properties of koumiss will make an important contribution to producing, transportation and holding of this fermented product.

\section{References}

Abu-Jdayil B, Mohameed H. 2002. Experimental and modeling studies of flow properties of concentrated yogurt as affected by the storage time, J Food Eng, 52, 359-365.

Benchabane A, Bekkour K. 2008. Rheological properties of carboxymethyl cellulose (CMC) solutions, Colloid Poly Sci, 286, 1173-1180.

Bensmira M, Nsabimana C, Jiang B. 2010. Effects of fermentation conditions and homogenization pressure on the rheological properties of Kefir, Food Sci Technol, 43(8), 1180-1184.

Bozkurt H, Icier F. 2009. Rheological characteristics of quince nectar during ohmic heating, Int J Food Prop, 12, 844-859.

Di Cagno R, Tamborrino A, Gallo G, Leone C, de Angelis M, Faccia M, Amirante P, Gobbetti M. 2004. Uses of mares' milk in manufacture of fermented milks, Int Dairy J, 14, 767-775.

Geankoplis C.J. 2003. Transport Process and Unit Operations, 3th Edition, Prentice-Hall International, Inc.

Honer C. 1993. Now kefir, Dairy Field, 176(9), 91.

Icier F, Bozkurt H. 2010. The Investigation on Ohmic Heating of Milk and Reconstituted Milk: Effects on Rheological Behaviour, J Food, 35(4), 251-258.

Janhøj T, Frøst MB, Ipsen R. 2008. Sensory and rheological characterization of acidified milk drinks, Food Hydrocoll, 22, 798-806.

Köksoy A, K1lıc M. 2003. Effects of water and salt level on rheological properties of ayran, a Turkish yoghurt drink, Int Dairy J, 13(10), 835-839.

Kristensen D, Jensen PY, Madsen F, Birdi KS. 1997. Rheology and surface tension of selected processed dairy fluids: Influence of temperature, J Dairy Sci, 80(10), 2282-2290.

Kroger M. 1993. Kefir, Cult Dairy Prod, 28(2), 28-29.

Kurmann JA, Rašić JLj, Kroger M. 1992. Encyclopedia of Fermented Fresh Milk Products, Van Nostrand Reinhold, New York.

Malkin A. 1994. Rheology Fundamentals, Chemtec Publishing, Canada.

Mann EJ. 1989. Kefir and koumiss, Dairy Industries International, 54(9), 9-10

Marcotte M, Hoshahili RT, Ramaswamy HS. 2001. Rheological properties of selected hydrocolloids as a function of concentration and temperature, Food Res Int, 34, 695-703.

Sabanc1 S, Celebi C, İcier F. 2014. Rheological Properties of Sübye: A Traditional Beverage, Acad Food J, 12, 11-15.

Simova E, Beshova D, Qangelov A, Hristozova TS, Frengova G, Spasov Z. 2002. Lactic acid bacteria and yeasts in kefir grains and kefir made from them, J Ind Microbiol Biotech, 28, 1-6.

Steffe JF. 1996. Rheological Methods in Food Process Engineering, Freeman Press, MI, USA.

Tamime A. 2006. Fermented Milks, Blackwell Science Ltd. UK. 